\title{
Altitudinal effects on diversity of Pimplinae (Hymenoptera, Ichneumonidae) from Southeast Brazil and description of new species
}

\author{
P. T. Higa ${ }^{a}$ (D) and A. M. Penteado-Dias ${ }^{b}$ \\ aPrograma de Pós-Graduação em Ecologia e Recursos Naturais, Universidade Federal de São Carlos - UFSCar, \\ CP 676, CEP 13565-905, São Carlos, SP, Brasil \\ 'Departamento de Ecologia e Biologia Evolutiva, Universidade Federal de São Carlos - UFSCar, CP 676, \\ CEP 13565-905, São Carlos, SP, Brasil \\ *e-mail: pri.higaa@gmail.com
}

Received: August 3, 2018 - Accepted: August 13, 2018 - Distributed: February 28, 2020

(With 20 figures)

\begin{abstract}
In this study the diversity of Pimplinae at three different altitude zones in the Reserva Biológica da Serra do Japi Jundiaí, SP, Brazil was investigated with a total of 18 genera and 91 morphospecies collected by Malaise traps. Highest abundance and richness of Pimplinae were found in low and high altitudes, respectively. In the intermediate altitude occurred greater diversity and equitability, with greater similarity to high altitude. The genera Pimpla and Neotheronia were the most abundant; Pimpla caerulea Brullé, 1846 was the most frequent species. A new species of the genus Acrotaphus and two new species of the genus Polysphincta were found. Descriptions of the new species and identification keys are presented.
\end{abstract}

Keywords: diversity, altitude, Pimplinae, Acrotaphus, Polysphincta.

\section{Efeitos altitudinais na diversidade de Pimplinae (Hymenoptera: Ichneumonidae) da região sudeste do Brasil e descrição de novas espécies}

\section{Resumo}

Neste estudo a diversidade de Pimplinae em três diferentes altitudes na Reserva Biológica da Serra do Japi, Jundiaí, SP, Brasil foi investigada com um total de 18 gêneros e 91 morfoespécies capturadas por armadilhas Malaise. Nas altitudes baixa e alta ocorreram maior abundância e riqueza em gêneros, respectivamente. Na altitude intermediária ocorreu maior diversidade e equitabilidade, com maior similaridade na altitude alta. Os gêneros Pimpla e Neotheronia foram os mais abundantes. Pimpla caerulea Brullé, 1846 foi a espécie mais frequente. Uma nova espécie do gênero Acrotaphus e duas novas espécies do gênero Polysphincta foram encontradas. As descrições das novas espécies e as chaves de identificação são apresentadas.

Palavras-chave: diversidade, altitude, Pimplinae, Acrotaphus, Polysphincta.

\section{Introduction}

The Pimplinae constitutes the most primitive group of the family Ichneumonidae, comprehending more than 77 genera and 1,737 species occurring worldwide (Yu et al., 2016). In Brazil, 25 genera and 93 species were recorded (Fernandes et al., 2015). Biologically it is the most diverse group and this is related to the low specialization in host type and parasitoidism, represented by strategies both ecto- and endoparasitoid idiobionts, ectoparasitoid koinobiont and egg predators (Quicke, 2015). The genera Acrotaphus Townes (1960) and Polysphincta Gravenhorst (1829) belong to the tribe Ephialtini and occur mainly in the Neotropical region (Hanson and Gauld, 2006).

Acrotaphus is found in the New World with ten known species, nine of which occur in the Neotropical region (Yu et al., 2016). The species are exclusive ectoparasitoids of spiders from the families Araneidae and Tetragnathidae (Gauld et al., 2002; Gauld and Dubois, 2006). They usually exhibit nocturnal activity and can be attracted by kairormonal signs of spider silk that weave orbital webs at night (Gauld, 1991). Polysphincta is found in the Holartic and Neotropical regions with twenty-seven described species and nine in the Neotropical region (Yu et al., 2016). In the North America and Europe, their species are parasitoids of spiders of the family Araneidae that build orbicular tissues (Fitton et al., 1988; Gauld et al., 1998). The purpose of the present paper is to analyze the diversity of Pimplinae species at three different altitudes in a area of Atlantic Forest in Southeast of Brazil, describing new species and updating the known distribution of Acrotaphus and Polysphincta. 


\section{Material and Methods}

The Reserva Biológica da Serra do Japi is located in the municipality of Jundiaí (S 2313'56', W 46 $56^{\prime} 29^{\prime}$ '), Southeast of Brazil, and is one of the last large areas of continuous Atlantic Forest in the State of São Paulo. It has approximately $350 \mathrm{~km}^{2}$ and different types of vegetation due to variations in altitude, temperature, humidity and soil. At elevations of 700-900 m are constituted by semideciduous seasonal forest and those of $900-1,300 \mathrm{~m}$ present a semi-deciduous seasonal forest ("altitude forest"), that is, with a dense and gradual vegetation of dry and low forest (Rodrigues, 1986).

The insects were collected using Malaise Townes (1972) model traps for samplings performed from October to December, 2015 and in February, April, May, June, September and October, 2016 in three different altitude points: $896 \mathrm{~m}$ (S 2313'47', W 46 $55^{\circ}$ '23'), 1,082 m (S 2314'32', W 46 56'10") and 1,190 m (S 2313'56", W 4656'29").

The material was identified following Gauld (1991) and Gauld et al. (1998). Color pictures were taken with a Leica stereomicroscope with LAS software. The insects were deposited in the DCBU Collection (Departamento de Ecologia e Biologia Evolutiva, Universidade Federal de São Carlos, São Carlos, SP, Brazil).

Data analyses were performed using the software Excel (version 1805 of 2016) and software PAST (version 3.20 of 2018). The classification of Palma (1975) was performed by the combination of two Indices: Index of occurrence and Index of dominance. Thus, genera were classified in common (constant and dominant), intermediate (constant and accessory, constant and accidental, accessory and accidental, accessory and dominant, accessory and accessory) and rare (accidental and accidental).

To compare diversity at each different altitudes, the Shannon Diversity Index (H') was used. In order to estimate the real diversity according to the expected maximum diversity, the Equitability (J) (Pielou, 1975) analysis was used in a situation where all species were abundant. For analysis of similarity, the Jaccard $\left(\mathbf{S}_{\mathbf{j}}\right)$ was introduced, not considering the abundances of the species.

\section{Results and Discussion}

A total of 745 specimens of Pimplinae belonging to 18 genera were identified (Table 1). The most frequent genera were Pimpla (404 specimens or 54.23\%) and Neotheronia (122 specimens or $16.37 \%$ ), and the least frequent were Xanthopimpla (1), Scambus (1), Calliephialtes (2), Zaglyptus (2), Clydonium (3), Iseropus (4) and Apechthis (4). Among all genera, four were found exclusively at high altitude: Acrotaphus, Itoplectis, Scambus and Xanthopimpla. The genera that occurred at all altitudes and showed higher abundance at low altitude were Dolichomitus, Eruga, Pimpla, Polysphincta and Zonopimpla; Hymenoepimecis and Zatypota at intermediate altitude; and Clistopyga and Neotheronia at high altitude.

In relation to the sex of specimens found (Table 1), males (377 specimens, $50.6 \%$ ) had only small dominance upon females (368 specimens, 49.4\%), with predominance of Pimpla (281 males specimens, 74.5\%; 123 female

Table 1. Total number of specimens and respective sex ratios of Pimplinae in 18 genera captured by Malaise traps at low altitudes $(896 \mathrm{~m})$, intermediate $(1082 \mathrm{~m})$ and high $(1190 \mathrm{~m})$ at the Reserva Biológica da Serra do Japi, Jundiai, SP, Brazil.

\begin{tabular}{|c|c|c|c|c|c|c|c|c|}
\hline & $\begin{array}{c}\text { Low } \\
(896 \mathrm{~m})\end{array}$ & $\mathbf{C P}$ & $\begin{array}{c}\text { Intermediate } \\
(1082 \mathrm{~m})\end{array}$ & $\mathbf{C P}$ & $\begin{array}{c}\text { High } \\
(1190 \mathrm{~m})\end{array}$ & $\mathbf{C P}$ & N Total & $\begin{array}{c}\text { CP } \\
\text { Total }\end{array}$ \\
\hline Acrotaphus & - & - & - & - & $1+, 5 \AA$ & I & 6 & $\mathrm{R}$ \\
\hline Apechthis & - & - & 29 & $\mathrm{R}$ & $2 ㅇ$ & $\mathrm{R}$ & 4 & $\mathrm{R}$ \\
\hline Calliephialtes & - & - & $1 q$ & $\mathrm{R}$ & 1 우 & $\mathrm{R}$ & 2 & $\mathrm{R}$ \\
\hline Clistopyga & 2 우 & $\mathrm{R}$ & 8 ㅇ, $10^{\hat{O}}$ & I & 11 ㅇ, $1 \widehat{\jmath}$ & I & 23 & I \\
\hline Clydonium & $1 \delta^{\widehat{0}}$ & $\mathrm{R}$ & $1 ㅇ$ & $\mathrm{R}$ & 1 ㅇ & $\mathrm{R}$ & 3 & $\mathrm{R}$ \\
\hline Dolichomitus & $7 ㅇ, 1 \sigma^{\lambda}$ & I & 40 & $\mathrm{R}$ & $4 \bigcirc, 1 \hat{\jmath}$ & $\mathrm{R}$ & 17 & I \\
\hline Eruga & 14 우 & I & 5 우 & I & $1 ㅇ$ & $\mathrm{R}$ & 20 & I \\
\hline Hymenoepimecis & $2 ㅇ$ & $\mathrm{R}$ & $3 \circ, 1 \hat{\circ}$ & I & $1 ㅇ$ & $\mathrm{R}$ & 7 & $\mathrm{R}$ \\
\hline Iseropus & - & - & 29 & $\mathrm{R}$ & 2 우 & $\mathrm{R}$ & 4 & $\mathrm{R}$ \\
\hline Itoplectis & - & - & - & - & $7 q, 3 \hat{\jmath}$ & I & 10 & $\mathrm{R}$ \\
\hline Neotheronia & $12, 29 \lesssim$ & $\mathrm{C}$ & 16 ㅇ, $6 \overbrace{}^{\wedge}$ & $\mathrm{C}$ & $26 ㅇ, 33 \widehat{\jmath}$ & $\mathrm{C}$ & 122 & $\mathrm{C}$ \\
\hline Pimpla & $53, 121 \lesssim$ & $\mathrm{C}$ & $41, 46 \overbrace{}^{\wedge}$ & $\mathrm{C}$ & $29 \circ, 114 \lesssim$ & $\mathrm{C}$ & 404 & $\mathrm{C}$ \\
\hline Polysphincta & 12 ㅇ & I & 1 우 & $\mathrm{R}$ & 2 우 & $\mathrm{R}$ & 15 & I \\
\hline Scambus & - & - & - & - & 1 우 & $\mathrm{R}$ & 1 & $\mathrm{R}$ \\
\hline Zaglyptus & - & - & 1 우 & $\mathrm{R}$ & 1 우 & $\mathrm{R}$ & 2 & $\mathrm{R}$ \\
\hline Zatypota & 12 ㅇ & I & 24 + & $\mathrm{C}$ & 8 우 & I & 44 & $\mathrm{C}$ \\
\hline Zonopimpla & $19 q, 8 \hat{\jmath}$ & $\mathrm{C}$ & $16 q, 5 \hat{\jmath}$ & $\mathrm{C}$ & $11 q, 1 \widehat{\jmath}$ & I & 60 & $\mathrm{C}$ \\
\hline Xanthopimpla & - & - & - & - & $1 ㅇ$ & $\mathrm{R}$ & 1 & $\mathrm{R}$ \\
\hline TOTAL & $\mathbf{1 3 3} \odot, \mathbf{1 6 0} \overbrace{}^{\lambda}$ & & $\mathbf{1 2 5}+, \mathbf{5 9} \overbrace{}^{\lambda}$ & & $\mathbf{1 1 0}+, \mathbf{1 5 8} \overbrace{}^{\lambda}$ & & 745 & \\
\hline
\end{tabular}

$\mathrm{N}=$ frequency of individuals; $\mathrm{CP}=$ Classification of Palma (1975): $\mathrm{R}=$ rare; $\mathrm{I}=$ intermediate; $\mathrm{C}=$ common. 
specimens, 33.4\%) and Neotheronia (68 males specimens, $18 \%$; 54 females specimens, 14.7\%). To the genera Apechthis, Calliephialtes, Eruga, Iseropus, Polysphincta, Scambus, Zaglyptus, Zatypota and Xanthopimpla, were registered only females and most were found at intermediate and high altitude.

Considering the classification of Palma (1975), for occurrence and dominance at different altitudes, Neohteronia, Pimpla, Zatypota and Zonopimpla were considered common; Clistopyga, Dolichomitus, Eruga and Polysphincta were intermediate and the remainder rare (Table 1).

The temporal abundance of Pimplinae varied at each altitude (Figure 1a) reaching peaks of abundance in different periods of the year. They reached greatest abundance of specimens in October 2016 with 159 individuals and in November 2015 with 116 individuals (Figure 1b).

The diversity of Pimplinae in each altitude was analysed by the Shannon (H') and Equitability (J) Indices (Table 2). Abundance was highest at low altitude with 293 specimens and richness was highest at high altitude with 18 genera and 55 morphospecies. The intermediate altitude had the highest diversity Shannon index 1.74 and equitability $(66.12 \%)$. And this altitude in relation to high altitude were more similar (Figure 2).

A total of 91 morphospecies were found, including three described as new. Pimpla caerulea Brullé, 1846, Neotheronia hespenhedei Gauld, 1991 and N. tolteca (Cresson, 1874) were the most frequent species (Table 3). Pimpla and Neotheronia are the richest species in the neotropical region and are endoparasitoids idiobiont and ecto- or endoparasitoids idiobiont of Lepidoptera, respectively (Porter, 1970; Gauld, 1991). Similar results were found in Costa Rica (Gauld, 1991), Brazil (Pádua and Nunes, 2017; Kumagai, 2002) and Peru (Carrasco, 1972).

The enormous abundance of some species recorded in this study may be directly related to the great availability of hosts and / or the generalist way of life (idiobiont), as well as the altitude climate. According to Gauld et al. (1998), in environments below $1,000 \mathrm{~m}$, the species can be strongly influenced by the dry and humid climate. Species that are found exclusively in the dry forest of Costa Rica were Clistopyga chaconi Gauld, 1991, Pimpla sumichrasti Cresson, 1874, Neotheronia lloydi Gauld, 1991, Dolichomitus zonatus (Cresson, 1874); and species that are common but which may occur in rainforest are Neotheronia melosa Cresson, 1874, N. tacubaya (Cresson, 1874), N. rosai Gauld, 1991, Pimpla croceiventris (Cresson, 1868) and P. caerulea. These species can also be found in deforested areas, agroecosystems and urban gardens. Most of these species were also found at high frequency at altitude of $896 \mathrm{~m}$ in this study, which may indicate a region of drier climate and anthropogenic disturbances.

Other species with high frequency of occurrence were, respectively (Table 3): Zonopimpla carolinae Gauld, 1991, Pimpla croceiventris, Pimpla sumichrasti, Zatypota sp.6, Dolichomitus sp.2, Clistopyga sp.3, Eruga sp. 1, Polysphincta sp. nov. 1. First records to Brazil were: Zonopimpla aguillari Gauld, 1991 and Zonopimpla carolinae. a)

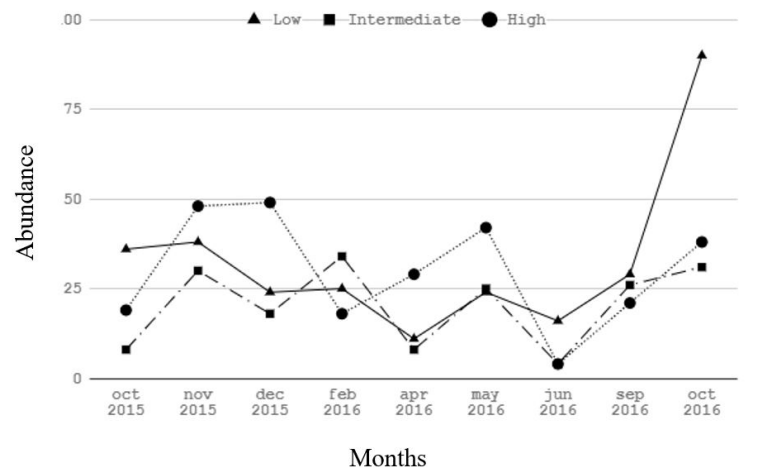

b)

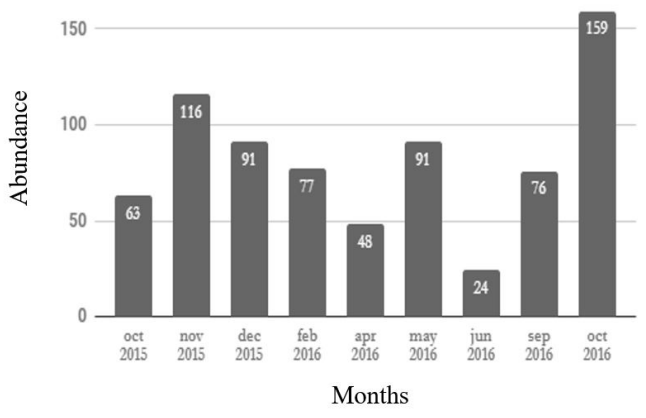

Figure 1. Frequence distribution of abundance of Pimplinae collected at Reserva Biológica do Japi, Jundiaí, SP, Brazil. (a) Specimens at low altitudes $(896 \mathrm{~m})$, intermediate $(1,082 \mathrm{~m})$ and high $(1,190 \mathrm{~m})$; (b) Total specimens collected in each month.

Table 2. Shannon Diversity Index and Equitability.

\begin{tabular}{cccccc}
\hline Altitudes & $\mathbf{N}$ & $\mathbf{S}$ & H' (nats) & H' max. (nats) & J (\%) \\
\hline Low $(896 \mathrm{~m})$ & 293 & 10 & 1,397 & 2,302 & 60,679 \\
Intermediate $(1,082 \mathrm{~m})$ & 184 & 14 & 1,745 & 2,639 & 66,129 \\
High $(1,190 \mathrm{~m})$ & 268 & 18 & 1,589 & 2,890 & 54,977 \\
\hline
\end{tabular}

$\mathrm{N}=$ Total number of individuals analyzed or sample size; $\mathrm{S}=$ Richness of genera; H' = Shannon Diversity Index; H' max = Maximum diversity; $\mathrm{J}=$ Equitability. 
Table 3. Species of Pimplinae and their respective frequencies at Reserva Biológica da Serra do Japi, Jundiaí, SP, Brazil.

\begin{tabular}{|c|c|c|c|}
\hline Species & $\mathbf{N}$ & Species & $\mathbf{N}$ \\
\hline Ephialtini & & Zonopimpla sp.1 & $3+, 5 \lesssim$ \\
\hline Acrotaphus japi sp. nov. & $1+9 \hat{\jmath}$ & Zonopimpla sp.2 & 19 \\
\hline Calliephialtes sp.1 & 29 & Zonopimpla sp.3 & $1+$ \\
\hline Clistopyga sp. 1 & 19 & Zonopimpla sp.4 & $3 q$ \\
\hline Clistopyga sp.2 & $1 \hat{\jmath}$ & Zonopimpla sp.5 & $5+$ \\
\hline Clistopyga sp.3 & 12 우 & Zonopimpla sp.6 & $2 \hat{\sigma}$ \\
\hline Clistopyga sp.4 & $7 ㅇ$ & Zonopimpla sp.7 & $2 q$ \\
\hline Clistopyga sp.5 & 19 & Pimplini & \\
\hline Clistopyga sp.6 & $1 \delta^{\lambda}$ & $\begin{array}{l}\text { Apechthis zapoteca sarsinae Costa } \\
\text { Lima, } 1951\end{array}$ & 4 우 \\
\hline Clydonium sp.1 & $1 \delta^{\pi}$ & Itoplectis sp. 1 & 19 \\
\hline Clydonium sp.2 & $1 q$ & Itoplectis sp. 2 & $69,3 \hat{0}$ \\
\hline Clydonium sp.3 & 19 & Neotheronia charli Gauld, 1991 & 29 \\
\hline Dolichomitus sp.1 & $1 ㅇ$ & Neotheronia cyrusi Gauld, 1991 & $3 \hat{\sigma}$ \\
\hline Dolichomitus sp.2 & $13+, 1 \lesssim$ & Neotheronia hespenheidei Gauld, 1991 & $14+, 8 \widehat{0}$ \\
\hline Dolichomitus sp.3 & 19 & Neotheronia jugaldei Gauld, 1991 & $12 \hat{\jmath}$ \\
\hline Dolichomitus sp.4 & $1 \delta$ & Neotheronia lineata (Fabricius, 1804) & $2 \lesssim$ \\
\hline Eruga sp.1 & 12 운 & Neotheronia lloydi Gauld, 1991 & $8 \hat{\jmath}$ \\
\hline Eruga sp.2 & $2 q$ & Neotheronia matamorosi Gauld, 1991 & $1 q$ \\
\hline Eruga sp.3 & $3+$ & $\begin{array}{l}\text { Neotheronia montezuma (Cresson, } \\
1874 \text { ) }\end{array}$ & $6 \hat{\jmath}$ \\
\hline Eruga sp.4 & 3 우 & Neotheronia murilloi Gauld, 1991 & $1+4{ }^{\Uparrow}$ \\
\hline Hymenoepimecis sp.1 & $2+$ & Neotheronia tacubaya (Cresson, 1874) & $2 \uparrow, 1 \AA$ \\
\hline Hymenoepimecis sp.2 & 1 우 & Neotheronia tolteca (Cresson, 1874) & $12+, 10{ }^{\lambda}$ \\
\hline Hymenoepimecis sp.3 & 19 & Neotheronia sp.1 & 2 ㅇ \\
\hline Hymenoepimecis sp.4 & $1+1{ }^{\Uparrow}$ & Neotheronia sp.2 & $4 \stackrel{\circ}{+} 6 \overbrace{}^{\lambda}$ \\
\hline Hymenoepimecis sp.5 & 19 & Neotheronia sp.3 & $1 \delta$ \\
\hline Iseropus sp.1 & $1+$ & Neotheronia sp.4 & $5+2 \widehat{\jmath}$ \\
\hline Iseropus sp. 2 & $2+$ & Neotheronia sp.5 & $1 \hat{\sigma}$ \\
\hline Iseropus sp.3 & $1+$ & Neotheronia sp.6 & $1+$ \\
\hline Polysphincta jundiai sp. nov. & $13+$ & Neotheronia sp.7 & $1+$ \\
\hline Polysphincta soaresi sp. nov. & $2 q$ & Neotheronia sp. 8 & $1 q$ \\
\hline Scambus sp.1 & 1 우 & Neotheronia sp.9 & 3 우 \\
\hline Zaglyptus sp.1 & $2 q$ & Neotheronia sp.10 & $2 \sigma^{\lambda}$ \\
\hline Zatypota sp.1 & $5 q$ & Neotheronia sp.11 & $4 q$ \\
\hline Zatypota sp.2 & $5+$ & Neotheronia $\mathrm{sp} .12$ & $1+$ \\
\hline Zatypota sp.3 & $2+$ & Neotheronia $\mathrm{sp} .13$ & $1 \hat{\sigma}$ \\
\hline Zatypota sp.4 & 19 & Neotheronia sp.14 & $1 \delta$ \\
\hline Zatypota sp.5 & 69 & Pimpla azteca Cresson, 1874 & $1+1{ }^{\Uparrow}$ \\
\hline Zatypota sp.6 & $16+$ & Pimpla caerulea Brullé, 1846 & $104 ㅇ, 221 \lesssim$ \\
\hline Zatypota sp.7 & 19 & Pimpla croceiventris (Cresson, 1868) & $2+, 22 \hat{\jmath}$ \\
\hline Zatypota sp.8 & 1 우 & Pimpla perssoni Gauld, 1991 & 10 ㅇ \\
\hline Zatypota sp.9 & 19 & Pimpla sumichrasti Cresson, 1874 & $1 q, 21 \widehat{\jmath}$ \\
\hline Zatypota sp.10 & $1 q$ & Pimpla sp.1 & $8 \hat{\sigma}$ \\
\hline Zatypota sp.11 & 19 & Pimpla sp.2 & $3 ㅇ ㅜ 10^{\Uparrow}$ \\
\hline Zatypota sp.12 & $2+$ & Pimpla sp.3 & $2+, 5 \AA$ \\
\hline Zatypota sp.13 & 1 우 & Pimpla sp.4 & $2 \widehat{\delta}$ \\
\hline Zonopimpla agullari Gauld, 1991 & $1 \sigma^{\lambda}$ & Xanthopimpla aurita Krieger, 1915 & $1+$ \\
\hline Zonopimpla carolinae Gauld, 1991 & 31 ㅇ, $6 \overbrace{}^{\circ}$ & & \\
\hline
\end{tabular}

$\mathrm{N}=$ frequency of individuals. 


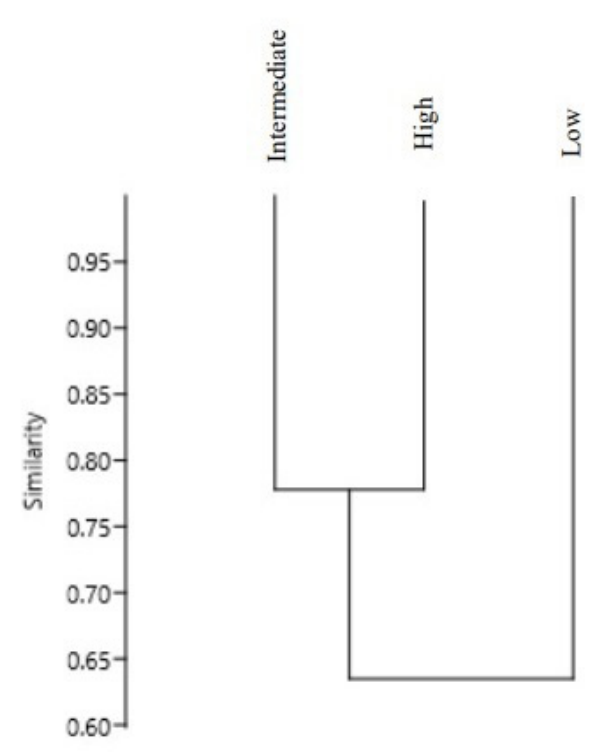

Figure 2. Jaccard Similarity Dendrogram calculated between low $(896 \mathrm{~m})$, intermediate $(1,082 \mathrm{~m})$ and high $(1,190 \mathrm{~m})$ altitudes in the Reserva Biológica da Serra do Japi, Jundiaí, SP.

\subsection{Description of the new species}

Acrotaphus japi sp. nov.

(Figures 3-8)

Female (Holotype) (Figure 3): Body length $14.7 \mathrm{~mm}$; fore wing length $13.2 \mathrm{~mm}$; hind wing length $9.8 \mathrm{~mm}$; antenna broken; lower face 0.9-1.0 times as broad as high, clypeus convex (Figure 4); mandibular reaching the margin of eye. Head in dorsal view with a concave genae behind eyes; ocelli exceptionally large reaching margin of eye (Figure 5). Pronotum long, so that distance from the back of the head to the tegula is about 0.4 times distance from tegula to hind margin of propodeum; epomia absent; mesoscutum smooth; scutellum convex; mesopleuron and metapleuron with hairs uniformly distributed, except for the posterocentral region which is smooth; epicnemial carina present strongly ventrally, laterally extended to almost reach level of lower corner of pronotum; metapleuron without submetapleural carina. Propodeum smooth, anteriorly and laterally with fine setiferous punctures, propodeal spiracle oval. Vein $\mathrm{cu}$ - $a$ more or less opposite base of $R S \& M, 2 r s-m$ with about 0.6-0.7 times as long as abscissa of $M$ between $2 r s-m$ and $2 m-c u$; hind wing with abscissa of $C u l$ between $M$ and $c u-a 1.0$ times legth of $c u-a$. Metasoma slender with tergites 1-3 with more spaced hairs and tergite 4+ with many hairs. Tergite 1 1.7-2.3 times as long as broad posteriorly and lateral carinae only present at anterior region; tergite 2 1.3-2.0 times as long as broad posteriorly; tergito $31.2-1.3$ as long as broad posteriorly; sternite 1 with a swelling near hind end. Ovipositor straight, $6.3 \mathrm{~mm}$ length and 1.4 times as long as hind tibia, apically very fine.

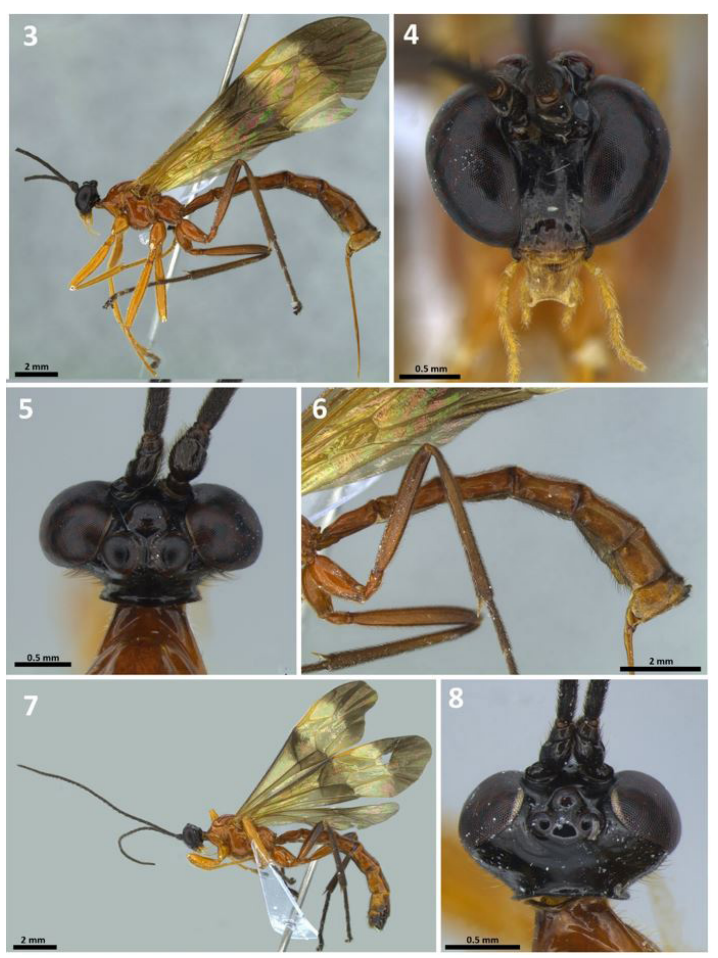

Figures 3-8. Acrotaphus japi sp. nov., female. (3) habitus; (4) face; (5) head and mesosoma; (6) ocelli; figures $(7,8)$ Acrotaphus jundiai sp. nov., male. (7) habitus; (8) ocelli.

Head black with yellowish orange mouthparts, clypeus orange or brownish. Antenna black ventral and dorsally in the basal region; mesosoma, metasoma (Figure 6) and ovipositor entirely orange. The fore and mid legs orange; hind legs orange with femur, tibia and tarsus orange brown; fore wing yellowish with blackish bands (one before pterostigma and one after vein $2 r s-m$ ), pterostigma yellow. Ovipositor orange and ovipositor sheaths black.

Male (Figure 7): Similar to female except for body length shorter than female, fore wing length 7.9-11,2 mm; ocelli smaller, the lateral one separated from eye margin by about 0.5 times its own diameter (Figure 8); metasoma a little stouter than that of female, with tergite 1 stouter; and tergite $6+$ blackish.

Material examined: Holotype, 1 ( (DCBU 209459), 1 đิ (DCBU 209460), Brazil, SP, Jundiaí, Reserva Biológica da Serra do Japi, S 23¹3'56”, W 4656'29”, Atlantic forest, 30-XII-2015, 1190 m, A. S. Soares \& L.A.M.Soares col. Paratypes, same holotype; 2 ๙ (DCBU 320053, 320054); 1 đ̊ (DCBU 209454), 02-II-2016; and 1 (DCBU 320052), 08-V-2016.

Comments: Acrotaphus japi sp. nov. differs from A. tibialis (Cameron, 1886) by presents metasoma evenly orange on the female (Figure 6); with tergites 6+ black in A. tibialis; ovipositor orange ; black or reddish brown in A. tibialis; hind leg with orange coxa and brown hind tibia, femur and tarsi ; hind legs orange with femur, distal 0.3 of tibia and tarsus dark reddish brown to blackish 
in A. tibialis; $2 r s-m$ always shorter than the abscissa of $M$ between $2 r s-m$ and $2 m-c u$; hind wing with abscissa of $C u 1$ between $M$ and $c u-a$ 0.5-1.0 times length of $c u-a$.

Distribution: Jundiaí, São Paulo State, Brazil

Etymology: The name of species refers to locality of collection Reserva Biológica da Serra do Japi in Jundiaí, SP, Brazil.

\subsubsection{Key to species of Acrotaphus modified from Gauld (1991) and Gauld et al. (1998)}

1.Female; ovipositor projecting conspicuosly beyong apex of metasoma.

- Male. ...2

2. Head, in dorsal view, with ocelli very large, the lateral one virtually touching the margin of the eye; concave gena behind eye; metasoma very slender, tergite $3>1.30$ times as long as broad posteriorly ....

- Head, in dorsal view, with ocelli only moderately large, the lateral one separated from the margin of the eye by more than 0.2 times its own maximum diameter; gena narrowed behind eye, but not concave; metasoma moderately slender, tergite $3<1.20$ times as long as broad posteriorly....

3. Epicnemial carina only present ventrally, not extending onto lateral face of mesopleuron; hind coxa blackish; metasoma with posterior margins of tergite 2-4 narrowly black.

latifasciatus Cameron

- Epicnemial carina extending laterally onto mesopleuron, its upper end reaching to about level of lower corner of pronotum; hind coxa orange; metasoma anteriorly more or less entirely orange, posterior margins of tergite 2-4 not black marked.

4. Ovipositor 1.2-1.3 times as long as hind tibia; metasoma with tergites 1-4 orange, 5+ blackish, hind leg with tibia more or less entirely black or blackish......

fasciatus Brullé

- Ovipositor $>1.3$ times as long as hind tibia; metasoma with tergites entirely orange or 1-5 orange, $6+$ blackish; hind leg with tibia entirely orange brown, or yellowish brown with only distal 0.3 black.

5. Metasoma with tergites entirely orange (Figure 6); hind leg orange with femur and tibia entirely orange brown (Figure 1)

.japi sp. nov.

- Metasoma with tergites 1-5 orange, 6+ blackish; hind leg with tibia orange or yellowish brown, with only distal 0.3 black.....

tibialis Cameron

6. Mesosoma orange with prothorax, mesoscutum and anterior part of mesopleuron black; hind coxa distally blackish; scutellum, in profile, simply convex.

franklini Gauld

- Mesosoma entirely orange; hind coxa orange; scutellum, in profile, almost pyramidal.

chedelae Gauld

7. Head in dorsal view with ocelli very large, the lateral one more or less touching the margin of the eye; epicnemial carina only present ventrally, not extending onto lateral face on mesopleuron; metasoma with posterior margins of tergites 2-4 narrowly black.

...latifasciatus Cameron
- Head in dorsal view with ocelli moderately medium to large, the posterior separated from margin of eye by 0.1 or more times its own maximum diameter; epicnemial carina extending laterally onto mesopleuron, its upper end reaching to about level of lower corner of pronotum; metasoma with tergites 2-4 generally entirely orange............................................. 8

8 (7). Mesosoma orange with prothorax, mesoscutum and anterior part of mesopleuron black; metasoma quite stout, with tergite 3 transverse, $<1.0$ times as long as broad posteriorly...

franklini Gauld

- Mesosoma entirely orange; metasoma quite slender, with tergite 3 elongate, $>1.10$ times as long as posteriorly broad.

9. Metasoma with tergites 1-4 orange, 5+ blackish; hind leg with tibia more or less entirely black or blackish.

fasciatus Brullé

- Metasoma with tergites 1-5 orange, 6+ blackish; hind leg with tibia entirely orange or yellowish brown, or tibia yellowish brown with only distal 0.3 black.

10. Hind leg orange with tibia entirely orange or yellowish brown (Figure 5) ........japi sp. nov.

- Hind leg with tibia yellowish brown, with only distal 0.3 black tibialis Cameron

Polysphincta jundiai sp. nov.

(Figures 9-15)

Female (Holotype) (Figure 9). Body length $6.0 \mathrm{~mm}$; fore wing length $4.0 \mathrm{~mm}$; hind wing length $3.0 \mathrm{~mm}$; antenna with 26 segments; lower face as broad as high,
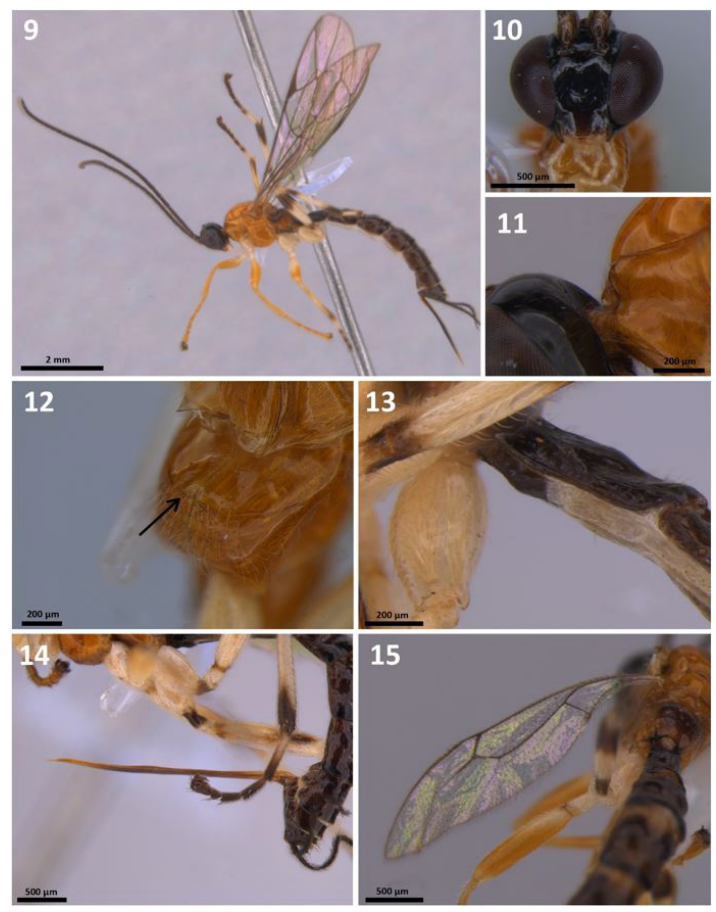

Figures 9-15. Polysphincta jundiai sp. nov., female. (9), habitus; (10) face; (11) epomia; (12) epicnemial carina; (13) sternite 1; (14) ovipositor; (15) hind wing. 
smooth with some hairs, clypeus weakly convex with apical margin truncate (Figure 10); malar space about 0.5 times as long as basal mandibular width. Head in dorsal view with genae moderately long, narrowed behind eyes; ocelli moderately large, the lateral one separated from eye by slightly less than its own maximum diameter. Pronotum with a very strong, long epomia (Figure 11), without a mediodorsal shelf-like projection, with a transverse groove with an incomplete mediodorsal longitudinal raised keel; mesoscutum smooth and polished, with notauli slightly impressed anteriorly; scutellum convex, not laterally carinated; mesopleuron smooth and polished without setiferous punctures; epicnemial carina ventrally strong (Figure 12); metapleuron convex, smooth and highly polished, without a submetapleural carina. Propodeum mediodorsally smooth and polished, with two anterior middle projections and posterolateral impressions near hind margin. Vein $\mathrm{cu}-\mathrm{a}$ distal to base of $R s \& M$ by 0.2 times its own length; base of $1 m-c u$ separated from $C u l a$ subequal to $C u 1 b$; hind wing with distal abscissa of $R s$ as long as $r s-m$. Metasoma slender with all tergites highly polished, at most with only a few punctures centrally. Tergite 11.2 times as long as broad posteriorly, dorsally with lateromedian longitudinal carinae discernible anteriorly; tergite 31.1 times as long as broad posteriorly; sternite 1 with a swelling near hind end (Figure 13), and with a weak median longitudinal ridge anteriorly. Ovipositor straight, 1.4-1.8 times as long as hind tibia, apically evenly tapered to a sharp point; subgenital plate subquadrate.

Head black with whitish mouthparts (Figure 10); except the tip of the mandible. Antenna dark brown; mesosoma orange, except for tegula which is whitish, and propodeum which is blackish anteriorly. Fore legs yellowish except coxa, trochanter and trochantellus whitish; mid legs whitish except trochanter basally, femur, tibia and tarsus apically; hind legs whitish except trochanter basally, femur and tibia basally and apically, and most tarsomeres blackish. Wings hyaline, pterostigma blackish. Metasoma with tergites brown; tergite 1 with apical margin blackish, sternites white with marginal lateral marks as well the mostly subgenital plate blackish. Ovipositor brownish (Figure 14) and ovipositor sheaths black.

Male. Unknown

Material examined: Holotype, 1 (DCBU 320055). Brazil, SP, Jundiaí, Reserva Biológica da Serra do Japi, S 2314'32', W 4656'10", Atlantic forest, 22.X.2015, 1,082 m, A. S. Soares \& L.A.M.Soares col. Paratypes, same holotype, 2 (DCBU 320056, DCBU 320057), S 2313'47', W 4655'23", 896 m; 1 (DCBU320059), 30.XII.2015, S 2313'47', W 465'23', 896 m; 1 (DCBU320060), 13.VI.2016, S $23^{\circ} 13^{\prime} 47^{\prime}$ ', W 4655'23', $896 \mathrm{~m}$; 5 ( (DCBU 320061-DCBU320065), 25.X.2016, S $23^{\circ} 13^{\prime} 47^{\prime \prime}$, W 46 55'23", 896 m; 3 (DCBU 320066-DCBU320068), 04.IX.2016, S 2313'47”, W 4655'23”, 896 m.

Comments: Polysphincta jundiai sp. nov. is structurally similar to P. purcelli Gauld, 1991, but does not present a complete mediodorsal longitudinal crest projecting forwards from the hind lip of pronotum crossing the deep transverse groove. Those two species share the hind wing with distal abscissa of $\mathrm{Cu} 1$ absent (Figure 15), and $C u 1 \& c u$ - $a$ not angled at its former position, lower face elongated, 0.6-0.7 times as broad as high. It differs from P. mascoi Gauld, 1951, by general coloration and for presents hind wing with distal abscissa of $\mathrm{Cu} 1 \mathrm{absent}$, and $\mathrm{Cu} \& \mathrm{\&} u-a$ not angled at its former position; lower face elongate. This new species differs from $P$. thoracica (Cresson, 1974) by general coloration, antenna longer than metasoma; it differs from P. townesorum De Santis \& Millan, 1968 by the general coloration, without submetapleural carina, nervulus not interstitial, metasoma smooth, polished and glabrous.

Distribution: Jundiaí, São Paulo State, Brazil

Etymology: This species is named in reference to municipality of Jundiai, SP, Brazil where the material was collected.

\section{Polysphincta soaresi sp. nov.}

(Figures 16-20)

Female (Holotype) (Figure 16). Body length $10.0 \mathrm{~mm}$; fore wing length $7.0 \mathrm{~mm}$; hind wing length $5.0 \mathrm{~mm}$; antenna with 30 segments; lower face elongated 1.2 times as broad as high, smooth and bearing sparse hairs (Figure 17), clypeus weakly convex with apical margin truncate; malar space about 0.5 times as long as basal mandibular width. Head in dorsal view with genae moderately long, strongly narrowed behind eyes; ocelli moderately large, the lateral one separated from eye by its own maximum diameter. Pronotum with a very strong, long epomia, without a mediodorsal shelf-like projection, pronotum with a transverse groove with a incomplete mediodorsal longitudinal raised keel ; mesoscutum smooth and polished,

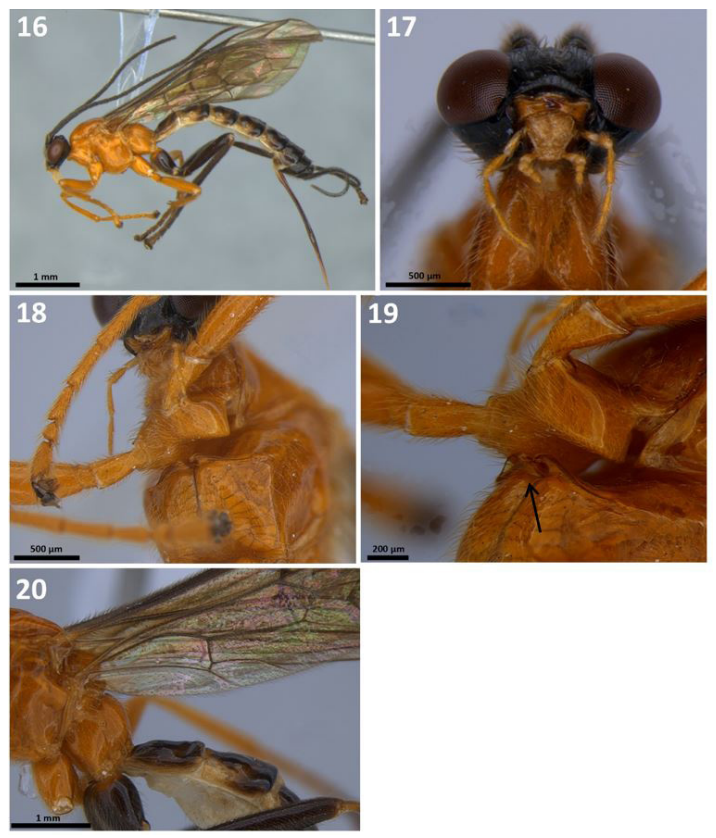

Figures 16-20. Polysphincta soaresi sp. nov., female. (16) habitus; (17) face; (18) epicnemial carina; (19) enlarged epicnemial carina; (20) hind wing. 
with notauli moderately impressed anteriorly; scutellum convex, not laterally carinated; mesopleuron polished, and glabrous, epicnemial carina not reaching to level of lower corner of pronotum, ventrally strong and with two posterior projections (Figures 18, 19); metapleuron convex, smooth and highly polished, without a discernible submetapleural carina. Propodeum mediodorsally smooth and polished, with posterolateral impressions near hind margin. Fore wing with $c u$ - $a$ distal to base of $R s \& M$ by 0.25 times its own length; base of $1 m-c u$ separated from Cula by more than length of $C u 1 b$; hind wing with distal abscissa of $R s$ longer than $r s-m$. Metasoma slender with all tergites highly smooth and polished, at most with only a few punctures laterally; tergite1 weakly broaded posteriorly, 1.1 times as long as posteriorly broad, dorsally with lateromedian longitudinal carinae only discernible anteriorly; sternite 1 with a weak swelling near hind end, and with a short wekly median longitudinal ridge anteriorly; tergite 3 transverse 1.2 times long as posteriorly broad. Ovipositor straight, 1.5 times as long as hind tibia, apically evenly tapered to a sharp point; subgenital plate subquadrate.

Head black with orange mouthparts (Figure 17); except the tip of the mandibles. Antennae very dark brown; mesosoma, fore and mid legs, orange, the hind legs blackish. Wings weakly infumate, pterostigma blackish. Metasoma with tergites brown with white marks at basal margin and a blackish at apical margin, sternites white, except the subgenital plate blackish. Ovipositor brownish and ovipositor sheath black.

Male. Unknown

Material examined Holotype, 1 (DCBU 320069). Jundiaí, SP Brazil, Reserva Biológica da Serra do Japi, S 2313'56”, W 4656'29', 1,190 m A. S. Soares \& L. A. M. Soares col. Paratype, same holotype, 1 q (DCBU 320070).

Comments: Polysphincta soaresi sp. nov. shares with $P$. purcelli, $P$. mascoi and $P$. jundiai sp. nov the submetapleural carina entirely absent, epomia long and strongly raised. It differs from the other species of Polysphincta for the transverse mediodorsally groove of pronotum without a longitudinal raised keel. This species shares with $P$. gutfreudi Gauld, 1991, the hind wing with distal abscissa of $\mathrm{Cul}$ distinct almost reaching to margin of wing (Figure 20), but presents the hind leg all black and the tergite 1 brown with anterior corners white and apical margin black. From $P$. thoracica this new species differs by general coloration and by ovipositor more than half of metasoma. From P. townesorum differs by the general coloration, without submetapleural carina, nervulus not interstitial, metapleuron and metasoma smooth, polished and glabrous. P. soaresi sp nov. differs from $P$. jundiai sp. nov. for the dimensions, epicnemial carina strong and with two projections ventrally, by the hind wing venation and by the general coloration.

Distribution: Jundiaí, São Paulo State, Brazil

Etymology: This species is named in honor of Airton Santos Soares the collector of the material.

\subsubsection{Key to females of species of Polysphincta} modified from Gauld (1991) and Gauld et al. (1998)

1.Submetapleural carina complete; female with ovipositor 0.8-0.9 times length of hind tibia; metasomal tergite 3 transverse, 0.8-0.9 times as long as broad posteriorly.

- Submetapleural carina entirely absent; female with ovipositor 1.2-1.4 times length of hind tibia; metasomal tergite 3 elongate, 1.1-1.3 times as long as broad posteriorly.

2. Hind wing with distal abscissa of $\mathrm{Cul}$ entirely absent; hind tibia brownish black with extreme proximal and distal apex white; tergite 2 blackish with anterior and anterolateral regions broadly white.

janzeni Gauld

- Hind wing with distal abscissa of $\mathrm{Cu} 1$ distinct; hind tibia white with a distal apical and a subbasal proximal black band; tergite 2 entirely black..................................... 3

3. Black face, only the apex of the white clypeo; mesoscutum with previously isolated or more or less broadly glabrous hairs gutfreundi Gauld

- Lower face cream white; epomia completely absent; mesoscutum covered with a densely distributed short pubescence. naranjae Gauld et al.

4. Epomia long and strongly raised; pronotum without a mediodorsal shelf-like projectio

- Epomia entirely absent; pronotum with a mediodorsal shelf-like projection arising from near hind margin and extending forwards

5. Pronotum mediodorsally with a transverse groove that is not centrally interrupted, epicnemial carina variable.

- Pronotum mediodorsally variable..............................7

6. Hind wing with distal abscissa of $C u 1$ absent (Figure 15), mesothorax orange (Figure 9), epicnemial carina ventrally with two projections (Figure 19)

jundiai sp. nov.

- Hind wing with distal abscissa of $C u 1$ vestigial but its position discernible by an angulation in $C u l \& c u-a$; mesothorax black, epicnemial carina without ventral projections. (Figure 12).

mascoi Gauld

7. Pronotum mediodorsally with a longitudinal raised keel which crosses the transverse groove centrally.

purcelli Gauld

- Pronotum mediodorsally with a transverse groove that is not centrally interrupted..

soaresi sp. nov

8 . Scape ventrally entirely white; hind leg predominantly white with black marks on trochanter, femur, tibia and tarsus; ovipositor 1.1-.1.2 times as long as hind tibia; female subgenital plate transverse.

dizardi Gauld

- Scape ventrally entirely black; hind leg with coxa reddish orange, remainder blackish or with femur reddish; ovipositor 1.2-1.4 times as long as hind tibia; female subgenital plate slightly elongated..... ..shabui Gauld 


\section{Acknowledgements}

To Coordenação de Aperfeiçoamento de Pessoal de Nível Superior (CAPES) for scholarship, to Conselho Nacional de Desenvolvimento Científico e Tecnológico (CNPq) and Fundação de Amparo à Pesquisa do Estado de São Paulo (FAPESP) for financial support to INCT dos Hymenoptera Parasitoides, and to administration of Reserva Biológica de Jundiaí for collections permits.

\section{References}

CARRASCO, F., 1972. Catalogo de la familia Ichneumonidae peruanos. Revista Peruana de Entomología, vol. 15, no. 2, pp. 324-332.

FERNANDES, D.R.R., SANTOS, B.F., PÁDUA, D.G. and ARAUJO, R.O., 2015 [viewed 13 June 2018]. Ichneumonidae. In: JARDIM BOTÂNICO DO RIO DE JANEIRO - JBRJ. Catálogo taxonômico da fauna do Brasil [online]. Rio de Janeiro: JBRJ. Available from: https://www.fauna.jbrj.gov.br/fauna/ faunadobrasil $/ 2248$

FITTON, M.G., SHAW, M.R. and GAULD, I.D., 1988. Pimpline ichneumonflies. Handbooks for the Identification of British Insects, vol. 7, pp. 1-110.

GAULD, I.D., 1991. The Ichneumonidae of Costa Rica, 1. Memoirs of the American Entomological Institute, vol. 47, pp. 1-589.

GAULD, I.D., GÓMEZ, J.A.U. and HANSON, P.S., 1998. Guía de los Pimplinae de Costa Rica (Hymenoptera: Ichneumonidae). Revista de Biología Tropical, vol. 46, pp. 1-189.

GAULD, I.D., WAHL, D.B. and BROAD, G.R., 2002. The suprageneric groups of the Pimplinae (Hymenoptera: Ichneumonidae): a cladistic re-evaluation and evolutionary biological study. Zoological Journal of the Linnean Society, vol. 136, no. 3, pp. 421-485. http://dx.doi.org/10.1046/j.1096-3642.2002.00031.x.

GAULD, I.D. and DUBOIS, J., 2006. Phylogeny of the Polysphincta group of genera (Hymenoptera: Ichneumonidae; Pimplinae): a taxonomic revision of spider ectoparasitoids.
Systematic Entomology, vol. 31, no. 3, pp. 529-564. http://dx.doi. org/10.1111/j.1365-3113.2006.00334.x.

HANSON, P.Y. and GAULD, I.D., 2006. Hymenoptera de la Región Neotropical. Gainesville: Memoirs of the American Entomological Institute, vol. 77.

KUMAGAI, A.F., 2002. Os Ichneumonidae (Hymenoptera) da Estação Ecológica da Universidade Federal de Minas Gerais, Belo Horizonte, com ênfase nas espécies de Pimplinae. Revista Brasileira de Entomologia, vol. 46, no. 2, pp. 189-194. http:// dx.doi.org/10.1590/S0085-56262002000200011.

PÁDUA, D.G. and NUNES, J.F., 2017. A checklist of Pimplinae (Hymenoptera, Ichneumonidae) from the Estação Ecológica dos Caetetus in São Paulo state, with new records of Neotheronia Krieger, 1899 from Brazil. The Journal of biodiversity data. Check List, vol. 13, no. 3, pp. 21-52. http://dx.doi.org/10.15560/13.3.2152.

PALMA, S., 1975. Contribución al estudio de los sifonoforos encontrados frente a la costa de Valparaiso: aspectos ecologicos. In: Anais do II Simposio Latinoamericano sobre Oceanografia Biologica, 1975, Venezuela. Venezuela: Univ. d'Orient, vol. 2, pp. 119-133.

PIELOU, E.C., 1975. Ecological diversity. New York: John Wiley, $165 \mathrm{p}$.

PORTER, C., 1970. A revision of the South American species of Coccygomimus (Hymenoptera, Ichneumonidae). Studia Entomologica, vol. 13, no. 1-4, pp. 1-192.

QUICKE, D.L.J., 2015. The braconid and ichneumonid parasitoid wasps: biology, systematics, evolution and ecology. Chichester: Wiley Blackwell, $688 \mathrm{p}$.

RODRIGUES, R.R., 1986. Levantamento florístico e fitossociológico das matas da serra do Japi, Jundiai, SP. Campinas: , Instituto de Biologia, Universidade Estadual de Campinas, 198 p. Dissertação de Mestrado em Biologia Vegetal.

TOWNES, H., 1972. A light-weight Malaise trap. Entomological News, vol. 83, pp. 239-247.

YU, D.S., VAN ACHTERBERG, C. and HORSTIMANN, K., 2016. World Ichneumonoidea: taxonomy, biology, morphology and distribution. Vancouver: Taxapad. 